\title{
HUBUNGAN POLA PEMBERIAN MAKAN DENGAN STATUS GIZI BALITA DI BAGAN PERCUT
}

\author{
Novita Aryani ${ }^{1}$; Henny Syapitri ${ }^{2}$ \\ ${ }^{1,2}$ Prodi S1 Keperawatan FFIKES Universitas Sari Mutiara Indonesia \\ Penulis korespondensi: novitaaryaniusm@gmail.com
}

\begin{abstract}
Toddlers are children who have reached the age of over one year or under five years, namely 24-60 months. This period is a challenge for parents because children find it difficult to eat, choose to eat, and like snacks with poor nutritional content such as instant noodles, which lead to a deficiency or excess intake of nutrients that can affect their nutritional status and health. The purpose of this study was to identify the relationship between feeding patterns and nutritional status in children under five in the Percut chart. The research design used in this study was cross-sectional. The population in this study was 67 people in Chart Percut with a sample size of 25 people who were taken using a simple random sampling technique. This study used a feeding pattern questionnaire and a $z$-score table. The results of the study were based on statistical analysis using the chisquare test with a significance level of $<0.05$, the result was $p=0.037$. A P-value less than 0.05 indicates $\mathrm{HI}$ is accepted and $\mathrm{HO}$ is rejected, meaning that there is a relationship between feeding patterns and nutritional status in children under five in Percut Sei Tuan District, Deli Serdang Regency. The correlation coefficient $(r)=0.069$, which means that it shows a strong relationship. The value of $r$ is positive, which means that the more appropriate the feeding pattern, the better the nutritional status of the toddler.
\end{abstract}

Keywords: Feeding pattern, nutritional status, children under five

\section{PENDAHULUAN}

Zat gizi dari makanan merupakan sumber utama untuk memenuhi kebutuhan tumbuh kembang optimal anak sehingga dapat mencapai kesehatan yang paripurna, yaitu sehat fisik, sehat mental, dan sehat sosial. Setiap harinya anak membutuhkan asupan gizi seimbang yang terdiri dari karbohidrat, protein, lemak, vitamin dan mineral. Asupan kandungan gizi tersebut dapat diperoleh dari makanan yang dikonsumsi yang berguna untuk pertumbuhan otak (intelegensia) dan pertumbuhan fisik (Sambo et al., 2020)
Untuk mengetahui status gizi dan kesehatan anak secara menyeluruh dapat dilihat mulai dari penampilan umum (berat badan dan tinggi badan), tandatanda fisik, motorik, fungsional, emosi dan kognisi anak. Berdasarkan pengukuran antropometri maka anak yang sehat bertambah umur, bertambah berat, dan tinggi. Salah satu cara penilaian status gizi balita adalah dengan pengukuran antropometri yang menggunakan indeks berat badan menurut umur $(\mathrm{BB} / \mathrm{U})$ dan dikategorikan dalam gizi lebih, gizi baik, gizi kurang, gizi buruk (Muzayyaroh, 2017). 
Berdasarkan data World Health Organitation (WHO) pada tahun 2017 lebih dari setengah kematian balita disebabkan oleh penyakit yang dapat dicegah dan diobati melalui intervensi sederhana dan terjangkau. Anak-anak yang kekurangan gizi, terutama mereka yang kekurangan gizi akut, memiliki risiko kematian yang lebih tinggi. Faktor-faktor yang berhubungan dengan gizi berkontribusi pada sekitar $45 \%$ kematian pada anak di bawah usia 5 tahun (Hanim, 2020).

Anak kurang gizi pada tingkat ringan dan atau sedang masih seperti anak-anak lain, beraktivitas, bermain dan sebagainya, tetapi bila diamati dengan seksama badannya mulai kurus dan staminanya mulai menurun. Pada fase lanjut (gizi buruk) akan rentan terhadap infeksi, terjadi pengurusan otot, pembengkakan hati, dan berbagai gangguan yang lain seperti misalnya peradangan kulit, infeksi, kelainan organ dan fungsinya (akibat atrophy /pengecilan organ tersebut) (Rahmadaniah, 2019).

Prevalensi balita dengan status gizi kurang yang cenderung meningkat apabila tidak diatasi dan akan menyebabkan masalah kesehatan yang lebih serius. Oleh sebab itu, perlu dilakukan upaya untuk menekan prevalensi balita dengan status gizi kurang yaitu dengan meningkatkan mutu gizi perorangan dan masyarakat, dengan cara memperbaiki pola konsumsi makanan yang sesuai dengan gizi seimbang, memperbaiki perilaku sadar gizi, aktivitas fisik, meningkatkan akses dan mutu pelayanan gizi sesuai dengan kemajuan ilmu pengetahuan dan teknologi, serta meningkatkan sistem kewaspadaan pada pangan dan gizi.(Khayati et al., 2017).

Pola makan merupakan perilaku paling penting yang dapat mempengaruhi keadaan gizi yang disebabkan karena kualitas dan kuantitas makanan dan minuman yang dikonsumsi akan mempengaruhi tingkat kesehatan individu. Gizi yang optimal sangat penting untuk pertumbuhan normal serta perkembangan fisik dan kecerdasan bayi, anak-anak serta seluruh kelompok umur. Pola makan merupakan tingkah laku seseorang atau kelompok orang dalam pemenuhan kebutuhan makan yang meliputi sikap, kepercayaan dan pilihan makanan. Pola makan terbentuk sebagai hasil dari pengaruh fisiologis, psikologis, budaya dan sosial (Lola, Margaretha, \& Sitompul, 2018).

Pada tahun 2019 jumlah anak balita di Dusun XVI Kecamatan Percut Sei Tuan terdapat 67 anak balita. Jumlah anak balita yang mengalami gizi kurang sebanyak 10 orang dan yang mengalami gizi buruk tidak ada. 
Berdasarkan pengamatan peneliti terdapat beberapa balita yang mengalami kondisi badan kurus, berambut pirang dan memiliki kulit tubuh yang kering. Kemudian pengetahuan ibu tentang pola makan anak, ibu menyebutkan anak tersebut jarang mengkonsumsi sayur- sayuran, susu, maupun buah-buahan. Selain itu, pola makan anak juga tidak teratur bisa sehari hanya dua kali saja. Dan jumlah makanan yang diberikan pada anak sehari hanya 1-2 piring nasi atau berkisar 4 sampai 6 sendok makan saja dan itupun tidak habis.

\section{METODE}

Jenis Penelitian merupakan penelitian deskriptif korelasi dengan rancangan cross sectional. Penelitian ini dilakukan di Dusun XVI Bagan Percut Kecamatan Percut Sei Tuan Kabupaten Deli Serdang pada bulan Mei-September Tahun 2020.

Populasi dalam penelitian ini adalah semua ibu dan balitanya yang berumur 1-5 tahun di Dusun XVI Bagan Percut Kecamatan Percut Sei Tuan Kabupaten Deli Serdang pada bulan April tahun 2020 yang berjumlah 67 orang. Sampel dihitung menggunakan rumus slovin sehinga didapat 25 orang, pengambilan sampel dengan cara simple random sampling yang memenuhi kriteria inklusi dan kriteria ekslusi. Pengukuran pola pemberian makan menggunakan lembar kuisioner yang dimodifikasi dari kuesioner Child Feeding Questionnaire (CFD) (Camci, Bas \& Buyukkaragoz, 2014).

Kuisioner yang digunakan dalam penelitian memiliki 15 pertanyaan, dimana setiap pertanyaan memiliki pilihan jawaban dengan skor 1 sampai 4 . Untuk memperoleh status gizi balita dilakukan dengan membandingkan Berat badan/Usia.

Peneliti akan menanyakan usia dan mengukur BB menggunakan timbangan digital, lalu mencatat pada lembar pencatatan. Kemudian untuk memperoleh status gizi balita dalam penelitian ini di gunakan tabel Standar Antropometri untuk menentukan kategori gizi buruk, gizi kurang, gizi baik dan gizi lebih. Kemudian data akan diproses dan dianalisa secara univariat dan bivariat. menggunakan uji Chi square.

\section{HASIL DAN PEMBAHASAN}

\section{Analisa Univariat}

Analisis Univariat pada penelitian ini akan menjelaskan usia, jenis kelamin dan berat badan responden, status gizi, pola makan balita. 
Tabel 1. Distribusi Frekuensi Karateristik Balita di Bagan Percut

\begin{tabular}{ccc}
\hline Karakteristik & Frekuensi $(\boldsymbol{f})$ & Persentase $(\%)$ \\
\hline Usia (Tahun ) & 5 & 20 \\
2 & 7 & 28 \\
3 & 9 & 36 \\
4 & 4 & 16 \\
5 & $\mathbf{2 5}$ & $\mathbf{1 0 0}$ \\
Total & & 40 \\
Jenis Kelamin & 10 & 60 \\
Laki-laki & 15 & $\mathbf{1 0 0}$ \\
Perempuan & $\mathbf{2 5}$ & \\
Total & & 4 \\
Berat Badan (Kg) & 1 & 16 \\
8 & 4 & 12 \\
10 & 3 & 4 \\
12 & 1 & 8 \\
13 & 2 & 24 \\
14 & 6 & 4 \\
15 & 1 & 12 \\
16 & 3 & 8 \\
17 & 2 & 8 \\
20 & 2 & $\mathbf{1 0 0}$ \\
22 & $\mathbf{2 5}$ &
\end{tabular}

Berdasarkan Tabel 1 diatas maka dapat diketahui bahwa sebagian besar responden memiliki usia 4 tahun sebanyak 9 orang (36\%), sedangkan usia 2 tahun sebanyak 5 orang (20\%), usia 3 tahun sebanyak 7 orang (28\%) dan usia 5 tahun sebanyak 4 orang $(16 \%)$.

Mayoritas responden berjenis kelamin perempuan sebanyak 15 orang (60\%) sedangkan berjenis kelamin lakilaki sebanyak 10 orang (40\%).
Responden yang memiliki berat badan $15 \mathrm{~kg}$ sebanyak 6 responden (24\%), $10 \mathrm{~kg}$ sebanyak 4 responden (16\%), $12 \mathrm{~kg}$ dan $17 \mathrm{~kg}$ masing-masing sebanyak 3 responden (12\%), $14 \mathrm{~kg} 20$ $\mathrm{kg}$ dan $22 \mathrm{~kg}$ masing-masing sebanyak 2 responden (8\%), $8 \mathrm{~kg} 13 \mathrm{~kg}$ dan $16 \mathrm{~kg}$ masing-masing sebanyak 1 responden (4\%). 
Tabel 2. Distribusi Frekuensi Karakteristik Ibu Balita di Bagan Percut

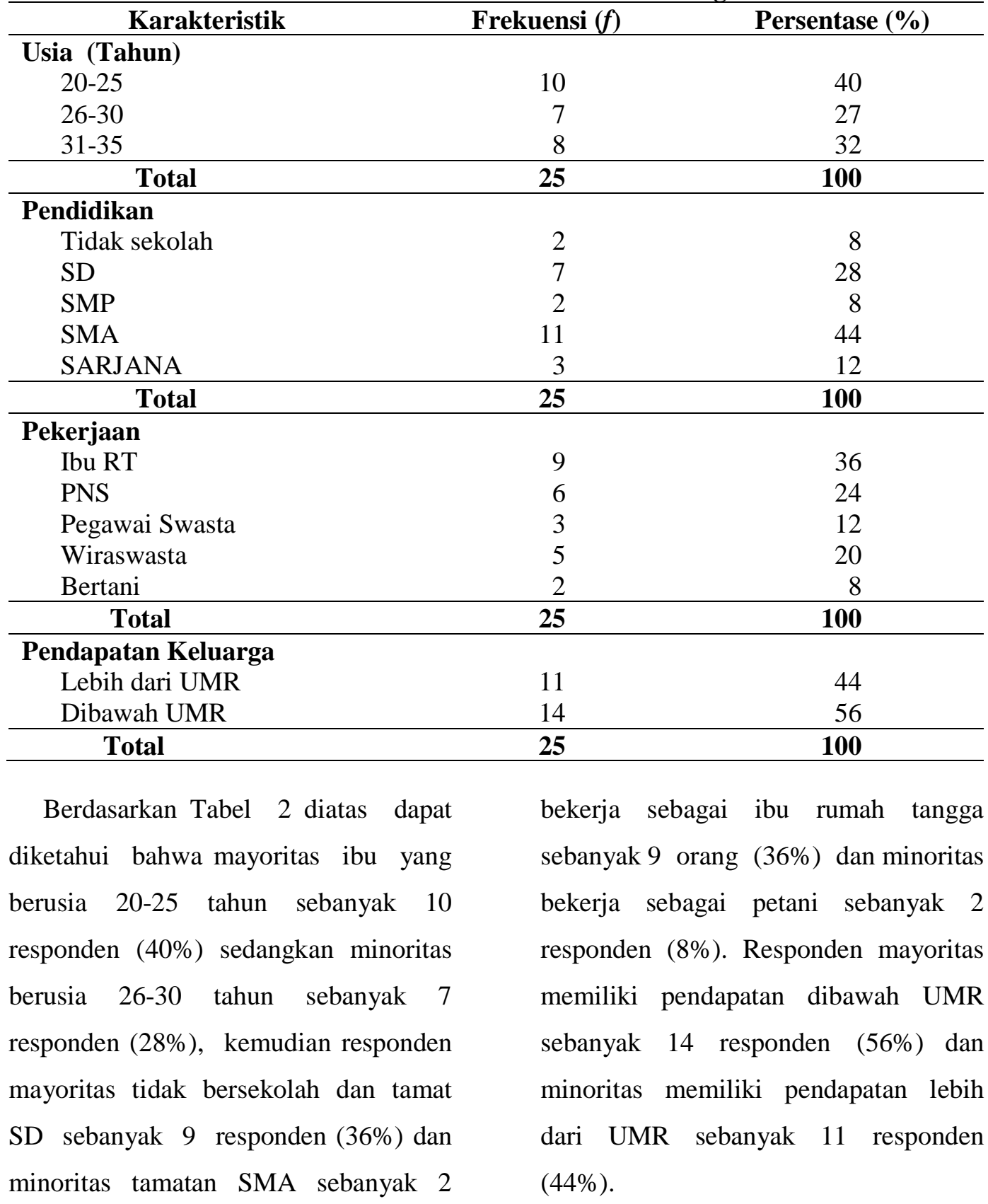

responden (8\%). Responden mayoritas

Tabel 3 Distribusi Frekuensi Ketepatan Pola Pemberian Makan pada Anak Balita

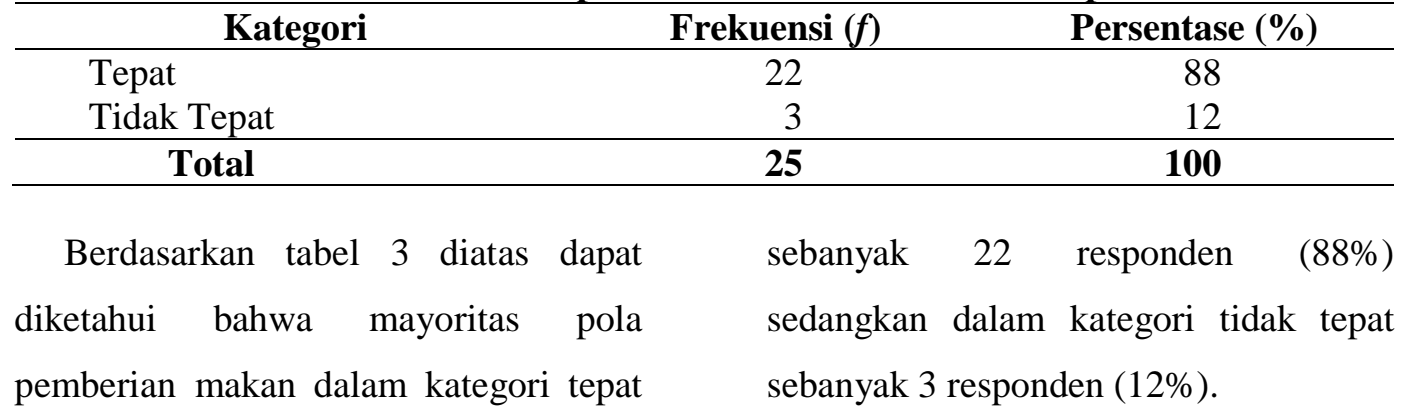


Tabel 4. Distribusi Frekuensi Status Gizi pada Anak di Bagan Percut

\begin{tabular}{ccc}
\hline Kategori & Frekuensi $(\boldsymbol{f})$ & Persentase (\%) \\
\hline Gizi Lebih & 0 & 0 \\
Gizi Baik & 3 & 12 \\
Gizi Kurang & 3 & 12 \\
Gizi Buruk & 0 & 0 \\
\hline Total & $\mathbf{2 5}$ & $\mathbf{1 0 0}$ \\
\hline
\end{tabular}

Berdasarkan Tabel 4 diatas dapat diketahui bahwa mayoritas status gizi dalam kategori baik sebanyak 22 responden (88\%), minoritas berada dalam kategori kurang sebanyak 3 responden $(12 \%)$.

\section{Analisa Bivariat}

Analisa bivariat menganalisa hubungan pola pemberian makan dengan status gizi pada anak balita, dapat dilihat pada tabel dibawah ini.

Tabel 5. Analisa Hubungan Pola Pemberian Makan dengan Status Gizi pada Anak Balita di Bagan Percut

\begin{tabular}{|c|c|c|c|c|c|}
\hline \multirow{3}{*}{ Pola Pemberian makan } & \multicolumn{4}{|c|}{ Status Gizi } & \multirow[t]{3}{*}{ PV } \\
\hline & Gizi & Gizi & Gizi & Gizi & \\
\hline & Lebih & Baik & Kurang & Buruk & \\
\hline Tepat & 0 & 16 & 0 & 0 & \multirow{2}{*}{0.037} \\
\hline Tidak Tepat & 0 & 6 & 3 & 0 & \\
\hline Total & 0 & 22 & 3 & 0 & \\
\hline
\end{tabular}

Berdasarkan Tabel 5 di atas dapat kita lihat bahwa dengan menggunakan uji Chi square dengan tingkat kemaknaan $<0,05$ didapatkan hasil $\mathrm{p}=0,037$. Nilai $\mathrm{p}$ lebih kecil dari 0,05 menandakan H1 diterima dan H0 ditolak, artinya terdapat hubungan pola pemberian makan dengan status gizi pada anak balita. Nilai koefisien korelasi $(r)=0,069$ yang berarti menunjukan hubungan yang kuat. Nilai $r$ bertanda positif yang memiliki makna bahwa semakin tepat pola pemberian makannya maka semakin baik pula status gizi balita tersebut.

\section{Pembahasan}

\section{Pola Pemberian Makan Balita}

Hasil penelitian ini didapati responden sudah menerapkan pola pemberian makan dengan kategori tepat yaitu sebanyak 22 responden (88\%), dimana ibu responden memberikan makan sesuai jadwal dan jenis makanan pada balita.

Pemilihan jenis makanan yang tepat yang dilakukan responden sudah mengandung zat gizi menu seimbang yaitu nasi, lauk pauk, sayur. Kandungan gizi makanan sudah terdapat karbohdrat, protein, lemak dan sayur. Responden menerapkan jadwal pemberian makan 
tepat waktu dengan jumlah 3 kali sehari dan ada makanan selingan diantara makanan utama.

Hal ini sejalan dengan penelitian Purwani et al., 2013 dalam penelitiannya mengatakan bahwa pola pemberian makanan balita yang baik sangat penting dibentuk sebagai upaya untuk memenuhi kebutuhan gizi dan pola makan yang tidak sesuai akan menyebabkan asupan gizi berlebih atau sebaliknya kekurangan. Seorang ibu yang telah menanamkan kebiasaan makan dengan gizi yang baik pada usia dini tentunya sangat mudah mengarahkan anak nya untuk makan karena anak telah mengenal makanan yang baik pada usia sebelumnya.

Sambo et al., (2020) dalam penelitiannya juga mengatakan bahwa anak usia prasekolah merupakan masa dimana pertumbuhan fisik dan psikologis bertumbuh dengan pesat. Pola makan pada anak usia prasekolah berperan penting dalam proses pertumbuahn dan perkembangan, Karena itu diperlukan makanan yang banyak mengandung zat gizi. Jika pola makan anak tidak tercapai dengan baik maka pertumbuhan dan perkembangan akan terhambat.

Menurut asumsi peneliti bahwa tepatnya pola pemberian makan responden kepada balita dikarenakan ibu memiliki pendidikan yang baik dan kebanyakan dari mereka bekerja diluar rumah untuk membantu perekonomian keluarga dimana anak balita mereka dititipkan kepada oarngtua (kakek dan nenek) Pendidikan ibu responden walaupun kebanyakan masih setingkat Sekolah Menengah Atas memberikan pengaruh bagi ibu dalam merawat anaknnya serta lingkungan pergaulan ibu yang bekerja memberi banyak pelajaran bagi ibu dalam memberikan pola makan anak balitanya, ditambah lagi asuhan kakek nenek yang selalu menjaga cucunya agar selalu sehat.

Hal ini sesuai dengan penelitian Milda dan Leersia (2018) mengatakan bahwa pola pemberian makan pada anak turut dipengaruhi oleh faktor fisiologis, psikologis, sosial, dan kebudayaan. Faktor- faktor tersebut mampu menentukan pilihan terhadap makanan apa saja yang akan dikonsumsi, sebanyak apa jumlah makanan yang dikonsumsi, siapa saja yang akan mengonsumsi, serta kapan makanan tersebut boleh atau tidak boleh untuk dikonsumsi.

\section{Status Gizi Balita}

Status gizi balita dalam penelitian ini dikategorikan gizi baik sebanyak 22 balita (88\%) setelah diukur menggunakan tabel standard antropometri dengan kategori -1 SD sampai +3 SD. 
Menurut asumsi peneliti status gizi balita dengan kategori baik dikarenakan pola pemberian makan yang baik yang dilakukan oleh ibu atau keluarga. Ibu responden yang mayoritas bekerja memiliki kemampuan untuk membelikan balita sejumlah makanan yang dapat mencukupi kebutuhan gizi balita, ditambah lagi ibu responden mayoritas berpendidikan menengah yang memiliki pengetahuan dalam pemberian makanan yang bervariasi, dan diikuti dengan menerapkan cara pemberian makan yang benar pada anak agar menghasilkan status gizi baik.

Hasil penelitian ini sesuai dengan penelitian terkait status gizi balita usia 3-4 tahun di Play Group Irsyadus Salam Sumber Sari Megaluh Kabupaten Jombang yang mendapatkan hasil status gizi balita kategori baik. Tetapi kebanyakan ibu balita menganggap balita sehat hanya dilihat dari fisik luar tanpa memperhatikan kondisi status gizinya. Padahal pada kenyataannya status gizi merupakan hal yang penting yang harus diperhatikan oleh para ibu balita karena juga akan mempengaruhi tumbuh kembang balita (Muzayyaroh, 2017).

Hasil penelitian ini juga sesuai dengan Khayati et al., (2017) yang mengatakan status gizi merupakan hal yang sangat penting harus diketahui orang tua terutama yang memiliki anak usia dibawah lima tahun karena anak balita merupakan kelompok usia yang menunjukkan pertumbuhan badan yang pesat sehingga anak memerlukan zat gizi yang tinggi setiap kilogram berat badannya dan merupakan masa emas yang terkait dengan pertumbuhan dan perkembangan masa selanjutnya.

\section{Hubungan pola pemberian makan dengan status gizi balita}

Hubungan antara pola pemberian makan dengan status gizi balita dalam penelitian ini menunjukkan bahwa adanya hubungan yang signifikan antara pola pemberian makan dengan status gizi pada anak balita. Nilai $\mathrm{p}=0,037$ dan koefisien korelasi $(r)=0,069$ yang berarti menunjukan hubungan yang kuat . Nilai $\mathrm{r}$ bertanda positif yang memiliki makna bahwa semakin tepat pola pemberian makannya maka semakin baik pula status gizi balita tersebut.

Hubungan antara pola makan dengan staus gizi balita terlihat pada hasil penelitian Sambo et al., 2020 yang mendapati ada hubungan pola makan kategori baik dengan status gizi kategori lebih. Status gizi lebih terjadi apabila tubuh memperoleh zat-zat gizi dalam jumlah berlebihan, sehingga menimbulkan efek toksis atau membahayakan. Anak yang memiliki berat badan lebih akan sering terlihat makan dengan porsi yang banyak. Dan mengalami kesulitan untuk bermain 
dengan teman-temannya akibat berat badan yang tidak sesuai.

Penelitian Yuliarsih (2020) yang menjelaskan bahwa konsumsi makanan atau dalam pola pemberian makan yang baik berpengaruh terhadap status gizi (pertumbuhan) balita. Status gizi baik bila tubuh memperoleh asupan gizi yang baik, sehingga memungkinkan pertumbuhan fisik dan kesehatan secara umum pada keadaan umum sebaik mungkin. Status gizi kurang terjadi bila tubuh mengalami kekurangan atau kelebihan zat gizi.

Pemberian makan pada balita bertujuan untuk memasukkan dan memperoleh zat gizi penting yang diperlukan oleh tubuh untuk proses tumbuh kembang. Zat gizi beperan dalam memelihara dan memulihkan kesehatan anak serta berguna sebagai sumber energi untuk melaksanakan aktivitas sehari-hari. Disamping makanan dari segi fisik, hal yang lain juga dibutuhkan anak untuk mencapai pertumbuhan dan perkembangan yang optimal yaitu, perhatian serta sikap (asuhan) orang tua dalam memberi makan. Kesalahan dalam memilihkan makanan akan berakibat buruk pada anak baik di masa kini maupun masa yang yang akan datang (Perdani et al., 2017).

Hal ini sejalan dengan penelitian (Prakhasita, 2018) status gizi balita stunting merupakan akumulasi dari kebiasaan makan terdahulu, sehingga pola pemberian makan pada hari tertentu tidak dapat langsung mempengaruhi status gizinya. Kunci keberhasilan dalam pemenuhan gizi anak terletak pada ibu. Kebiasaan makan yang baik sangat tergantung kepada pengetahuan dan keterampilan ibu akan cara menyusun makanan yang memenuhi syarat zat gizi.

Status gizi seseorang dipengaruhi oleh beberapa faktor, baik secara langsung maupun tidak langsung. Ketidak sesuaian antara jumlah gizi yang diperoleh dan kebutuhan gizi serta penyakit infeksi, seperti diare dapat memengaruhi status gizi secara langsung, tergantung pada besarnya dampak yang ditimbulkan. Faktor yang secara tidak langsung memengaruhi status gizi ialah pengetahuan, persepsi, kebiasaan makan, dan kondisi sosial ekonomi. (Hanim, 2020).

\section{KESIMPULAN DAN SARAN}

\section{Kesimpulan}

1. Pola pemberian makan yang diberikan kepada balita dalam penelitian ini sudah tergolong dalam kategori tepat

2. Status gizi yang terdapat pada balita di daerah tersebut tergolong dalam kategori baik 
3. Hubungan antara pola pemberian makan dengan status gizi balita dalam penelitian ini menunjukkan bahwa adanya hubungan yang signifikan

\section{Saran}

Bagi ibu atau orang tua harus memperhatikan pemenuhan kebutuhan gizi anak balita dalalm memberikan gizi seimbang dengan cara menentukan jenis makanan, jumlah makanan, dan jadwal makanan sesuai dengan kebutuhan anak sesuai usianya. Bagi petugas kesehatan di lingkungan Kelurahan Bagan Percut Kecamatan Percut Sei Tuan Kabupaten Deli Serdang dapat meningkatkan program- program yang sudah dilaksanakan, meningkatkan informasi terkait dengan status gizi balita serta meningkatkan upaya penerapan pemberian pola makanan yang baik bagi balita.

\section{DAFTAR PUSTAKA}

Hanim, B. (2020). Faktor yang memengaruhi status gizi balita di wilayah kerja Puskesmas Sidomulyo Kota Pekanbaru. JOMIS (Journal of Midwifery Science), 4(1), 15-24. https://doi.org/10.36341/jomis.v4i1.1 118

Khayati, F. N., Munawaroh, R., Studi, P., Keperawatan, I., \& Tengah, J. (2017). Hubungan pengetahuan ibu dan pola pemberian makanan terhadap status gizi anak. JURNAL EDUMidwifery, Vol. 1, No. 1, April 2017, 1, No 1. http

Lola V.L., Margaretha M., D. R., \& Sitompul. (2018). Hubungan pola pemberian makan dengan perilaku sulit makan pada anak usia pra sekolah (3-6). Keperawatan Suaka Intan (JKSI), 3 no. 2, 1-10.

Milda dan Leersia. (2018). Hubungan Pengetahuan Ibu tentang Pola Pemberian Makan dengan Status Gizi Balita di Wilayah Kerja Puskesmas Gapura Kabupaten Sumenep Relation Between Mothers ' Knowledge About Feeding Method and Toddlers ' Nutritional Status in the Working Area of Puskesma. 182188.

https://doi.org/10.20473/amnt.v2.i2.2 018.182-188

Muzayyaroh. (2017). Hubungan pola pemberian makan dengan status gizi balita usia 3-4 tahun di Play Group Irsyadus Salam. 1(1), 1-6.

Perdani, Z. P., Hasan, R., \& Nurhasanah, N. (2017). Hubungan praktik pemberian makan dengan status gizi anak usia 3-5 Tahun Di Pos Gizi Desa Tegal Kunir Lor Mauk. Jurnal JKFT, 1(2), 9. https://doi.org/10.31000/jkft.v2i2.59

Prakhasita, R. C. (2018). Hubungan pola pemberian makan dengan kejadian stunting pada balita usia 12-59 Bulan Di Wilayah Kerja Puskesmas Tambak Wedi Surabaya. Skripsi, 1119.

Purwani, E., Progam, M., Ilmu, S., Sekolah, K., Ilmu, T., Kendal, K., Ilmu, F., Semarang, U. M., \& Kedung, J. (2013). Pola pemberian makan dengan status gizi anak usia 1 sampai 5 tahun di Kabunan Taman Pemalang. 1.

Rahmadaniah, I. (2019). Hubungan Pemberian Makan Terhadap Status Gizi Batita Di Puskesmas Punti Kayu Palembang. 8(1), 1-8.

Sambo, M., Ciuantasari, F., \& Maria, G. (2020). Hubungan pola makan dengan status gizi pada anak usia prasekolah. Jurnal Ilmiah Kesehatan Sandi Husada, 11(1), 423-429. https://doi.org/10.35816/jiskh.v11i1. 316. 
Yuliarsih L, M. T. dan A. . (2020).

Pengaruh pola pemberian makan terhadap status gizi balita di wilayah kerja Puskesmas Astanajapura Kabupaten Cirebon. Syntax Literate : Jurnal Ilmiah Indonesia, 21(1), 1-9. http://mpoc.org.my/malaysian-palmoil-industry/ 